\title{
Histomorphology of the ovaries of the earthworm, Dendrobaena atheca Cernosvitov (Annelida, Clitellata: Oligochaeta)
}

\author{
GORGEES, N. S. ${ }^{1 *}$ and KHALID, V. A. ${ }^{2}$ \\ ${ }^{1}$ Department of Biology, Faculty of Science, University of Zakho, Kurdistan Regional Government, Iraq \\ ${ }^{2}$ Ministry of Education, Kurdistan Regional Government, Iraq \\ *E-mail: najem_gorgees@yahoo.com
}

\begin{abstract}
This comprehensive study was undertaken to reveal the ovarian histomorphology in the oligochaetous clitellte, Dendrobaena atheca Cernosvitov. Efforts were, in fact, made to obtain proper histological preparations. So, various types of thin serial sections of ovaries were carefully obtained, stained and examined. Two small ovaries, at the beginning of breeding seasons, were seen in segment thirteen. Subsequently, they extremely increased in size and became fully formed. They demonstrated six principal cell types: peritoneal cell, follicular cell, stromal cell, oogonium, oocyte and trophocyte (nurse cell). The first three cell types were somatic, whereas the other three were germ and germ-line. All cell types were, as much as possible, properly described. Dividing oogonia were seen to produce oocytes and trophocytes simultaneously. The produced cells were seen to be interconnected. The stromal cell, a newly described cell type, exhibited several specific cell characteristics. Ovaries showed no internal lumens. The small ovaries showed only two distinct histological zones, whereas the large ones showed three such zones. Germ and germ-line cells showed an obvious arrangement in ovarian zones. Accordingly, the chief conclusions are: (1) ovaries are nutrimental due to presence of trophocytes (2) ovaries are solid and not sac-like organs due the lack of internal cavity (3) stromal cell can be considered a new cell type as it demonstrates several specific cell features (4) Ovarian zonation is caused by production and arrangement of germ and germ-line cells (5) intercellular connections are due to incomplete cell divisions.
\end{abstract}

Keywords: solid nutrimental ovaries, trophocytes, oocytes, follicular cells, stromal cells.

\section{Introduction}

Comprehensive studies carried out on the ovaries of oligochaetous clitellates, unfortunately, were almost scarce and sporadic. Moreover, the ovaries of oligochaetous clitellates had been considered (DUMONT, 1969; CHAPRON and RELEXANS, 1971a, b; JAMIESON, 1981, 1992, 2006; ECKELBARGER, 2006) panoistic. According to this old view, the ovaries were devoid of trophocytes (nurse cells) and the oogonia were devoted to produce only oocytes (eggs). Thus, possibility of the presence of trophocytes in ovaries of oligochaetous clitellates had been entirely denied and/or rejected. Additionally, the ovaries of these annelids had been erroneously described as hollow or sac-like structures (ECKELBARGER, 2006).

On the other hand, an opposing view has concurrently appeared. Paschma (1962) has reported the presence of both trophocytes and oocytes in ovaries of the oligochaetous clitellate, Enchytraeus albidus. Ovaries with trophocytes are called nutrimental (meroistic). This view, however, found no proponents. Thus, it was neglected and forgotten for a long time. Luckily, Siekierska (2002) has recently revived and renewed PASCHMA's discovery. Siekierska and Urbanska-Jasik (2002) and Siekierska $(2003,2007)$ have successfully demonstrated the presence of trophocytes and oocytes simultaneously in ovaries of the oligochaetous clitellate, Dendrobaena veneta. Presence of the trophocytes has also been confirmed recently by Urbisz, Krodkiewska and Swiątek (2010) and Urbisz and Swiatek (2013) in other species of oligochaetous clitellates. Few experimental studies (PARTHASARATHI and RANGANATHAN, 2000; LAKHANI and KHATRI, 2008; LAKHANI, 2014) have also reported the presence of both trophocytes and oocytes in ovaries of such annelids.

Thus, the present study was, in fact, undertaken due to: (1) the shortage of comprehensive studies on histomorphology of ovaries in oligochaetous clitellates (2) the presence of some erroneous views and discrepancies about ovarian architecture of these annelids and (3) the failure of all old studies, except Paschma (1962), in describing trophocytes in ovaries of these annelids. Therefore, the chief aims of the present study were: (1) to describe carefully, thoroughly and comprehensively the histomorphology of the ovaries in Dendrobaena atheca (2) to show that the ovaries of this oligochaetous clitellate are also nutrimental (meroistic), and not panoistic as had incorrectly been considered previously and (3) to demonstrate that the ovaries are solid and not sac-like structures as had erroneously been described previously.

\section{Materials and Methods}

About 300 sexually mature earthworms, Dendrobaena atheca Cernosvitov, were used. They were collected during breeding seasons, spring and autumn, from villages of Duhok Governorate, Kurdistan Regional Government of Iraq.

Specimens of nearly the same length and with well-developed clitella and puberty tubercles were used. The segments 10-15 of the body, which were expected to contain the ovaries, were 
excised and fixed in alcoholic or modified BOUIN's fixative (DOBUSCQ-BRASIL's fixative) for 24 hours. They were washed for several days with $70 \%$ ethanol till they became pale yellow. They were dehydrated in $80 \%$, then $90 \%$ alcohols ( 15 minutes in each grade). Two successive changes, each of 15 minutes, of $95 \%$, then $100 \%$ alcohols were followed. These segments were cleared first in a mixture of equal volumes (1:1) of absolute ethanol and xylene for 15 minutes. Two changes of pure xylene, till the segments became quite clear and transparent, were used. They were then subjected for 15 minutes to a mixture of equal volumes (1:1) of molten paraffin wax (melting point $53-57^{\circ} \mathrm{C}$ ) and xylene in oven. Clearing was followed by embedding in two successive changes, each of 30 minutes, of pure molten paraffin wax in oven. Blocks were obtained, trimmed and fixed on microtome holder. Various types of serial sections: cross, horizontal and longitudinal of $5 \mu \mathrm{m}$ thickness, were cut using the rotary microtome (Kedee, China). They were neatly and carefully stretched, affixed on clean slides and stained with HARRIS' haematoxylin and alcoholic eosin. For histological preparations, Luna (1968) and Culling, Alliston and Barr (1985) were used.

The stained preparations were thoroughly examined under all objectives of the compound light microscope (Motic, Italy). Photomicrographs were obtained using digital camera (Samsung 7.1 mega pixels). Measurements of the dimensions of ovaries, various types of cells, their nuclei, nucleoli and other structures were calculated using 10X ocular lens, which was calibrated using stage micrometer.

\section{Results and Discussion}

\subsection{Gross morphology of ovaries}

Various types of the stained serial sections of the excised segments of $D$. atheca showed presence of a pair of ovaries in segment thirteen S13, one on either side of the fused double ventral nerve cord (Figure 1). Presence of only a pair of ovaries in segment 13 is, in fact, an important characteristic of all lumbricid species. These results are in line with those reported by Siekierska $(2002,2003)$, Lakhani and Khatri (2008) and
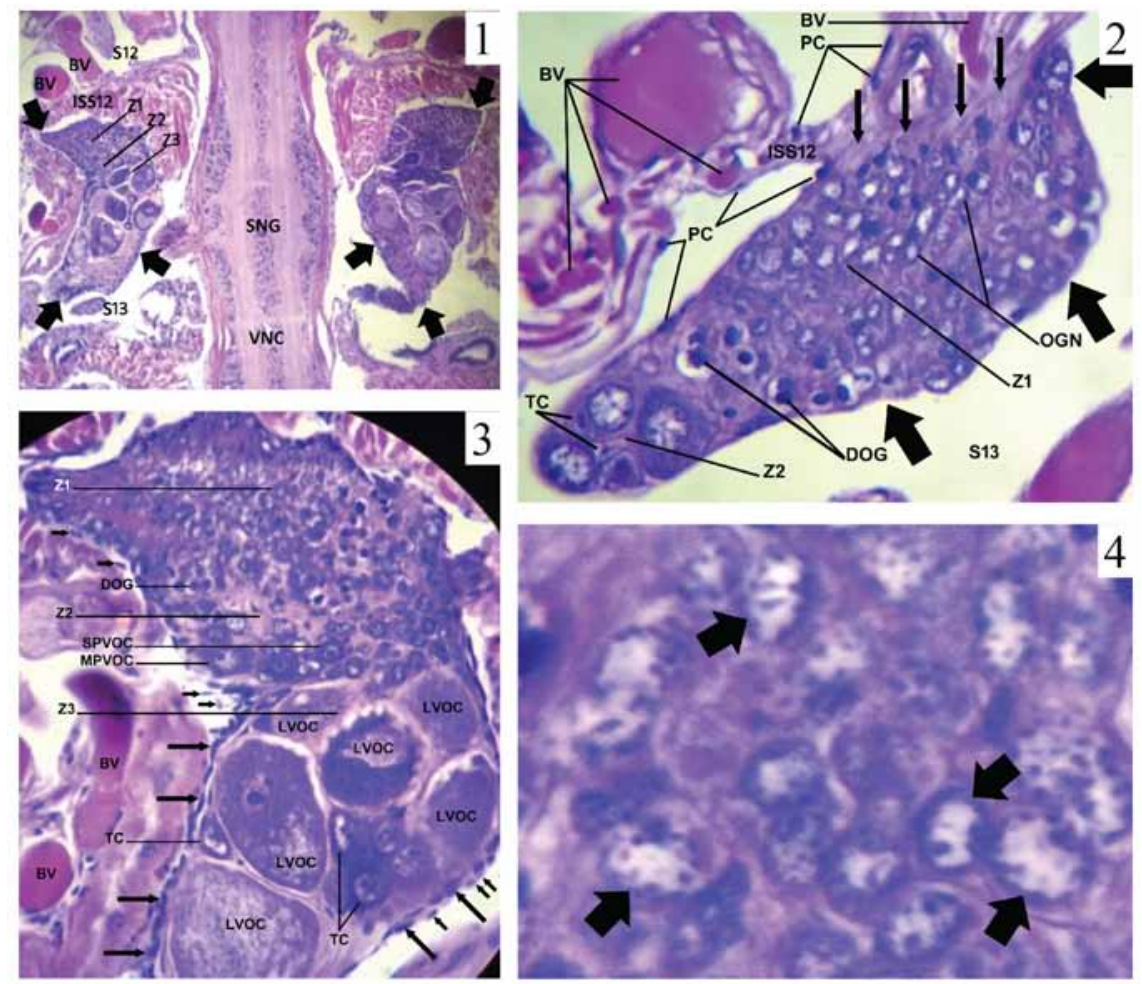

Figure 1-4. (1) A photomicrograph of a horizontal section of ovaries in D. atheca during the breeding seasons showing two fully formed ovaries (thick arrows). Z1, zone one; Z2, zone two; Z3, zone three; S12- segment twelve; S13- segment thirteen; ISS12-intersegmental septum 12; BV- blood vessels; VNC- ventral nerve cord; SNG- a segmental nerve ganglion of the VNC; (2) A photomicrograph of a horizontal section of ovary in $D$. atheca at the beginning of the breeding seasons showing a small ovary (thick arrows) with only two zones: zone one $\mathrm{Zl}$ and zone two $\mathrm{Z} 2$. The free apex of the ovary shows four distinct previteoolgenic oocytes PVOC and two small undeveloped trophocytes TC. Ovarian ligament, four thin vertical parallel arrows; ISS12- intersegmental septum 12 holding the ovary; OGN- nuclei of oogonia; DOG- dividing oogonia; BV- blood vessels in ISS12 and ovarian ligament; S13- segment 13; PC- peritoneal cells enveloping the ovary and the ISS12; (3) A photomicrograph of a horizontal section of the middle part of a fully formed ovary in $D$. atheca, during the breeding seasons showing three zones $(\mathrm{Zl}, \mathrm{Z2}, \mathrm{Z3})$. $\mathrm{Z1}$ contained only oogonia OG. DOG, dividing oogonia; Z2 contained small and medium previtellogenic oocytes (SPVOC, MPVOC) and small trophocytes (not shown); Z3- only a part of which is shown, contained large vitellogenic oocytes LVOC and fully formed trophocytes TC; short arrows, peritoneal cells enveloping the ovaries; long arrows, follicular cells forming the ovarian cortex; (4) A photomicrograph of a part of a longitudinal section of $\mathrm{Zl}$ of ovary in $\mathrm{D}$. atheca during the breeding seasons showing a crowded group of highly magnified oogonia. Thick arrows, nuclei of oogonia showing the nuclear membrane ornamented with chromatin granules. 
Vijaya, Middha, Usha et al. (2012). Vice versa, position of ovaries in the present study disagrees with that reported in tubificid species, such as T. hattai (HIRAO, 1964) and T. tubifex (URBISZ, KRODKIEWSKA and SWIĄTEK, 2010), in which the ovaries were situated in segment 11.

At the beginning of the breeding seasons, the ovaries (Figure 2) appeared as small inverted conical structures. The anterior end of the ovary was firmly tied to the posterior surface of the intersegmental septum twelve ISS 12 via a thin elastic ovarian ligament OL. The posterior end was freely extended into the coelom. It measured about $234 \mu \mathrm{m}$ in length and $82 \mu \mathrm{m}$ in width. The ovaries initially appeared small because they were built of only two relatively small zones, zone one $\mathrm{Zl}$ and zone two Z2. Conical ovaries have also been reported in other oligochaetous clitellates (SIEKIERSKA, 2002, 2003; URBISZ and SWIATEK, 2013).

Subsequently, ovaries extremely increased in size and extended along the entire length of $S 13$ when they were fully formed (Figure 1). Ovaries reached this enormous size due to the formation of zone three Z3 (Figures 1 and 3). Z3, which generally represents the largest ovarian zone, contains the huge sized oocytes and usually forms about two-thirds of the whole ovarian bulk. The fully formed ovaries appeared as two bunches of grapes (Figure 1) and measured about $900 \mu \mathrm{m}$ in length, $345 \mu \mathrm{m}$ in width and $235 \mu \mathrm{m}$ in thickness. The shape of the fully formed ovaries in the present study disagrees with the palmate shape, which has been described by Vijaya, Middha, Usha et al. (2012) and fan shape, which has been reported by Hirao (1964). The length of the fully formed ovaries in the present study is almost similar to that of E. kinnaeri (LAKHANI and KHATRI, 2008), which was $880 \mu \mathrm{m}$ and that of D. veneta (SIEKIERSKA, 2003), which was $1000 \mu \mathrm{m}$. But it greatly differs from that of E. engeniae (VIJAYA, MIDDHA, USHA et al., 2012), which approached $2000 \mu \mathrm{m}$ in length.

\subsection{Nourishment of ovaries}

The ISS 12 holding the ovaries was richly supplied (Figure 2) with large and small blood vessels and capillaries. Some of these blood vessels were seen to cross the OL and enter the ovaries. Ovarian blood supply seems to be indispensable as the blood stream transfers nutrients, hormones and oxygen to ovarian cells to support oogenesis, growth, development and vitellogenesis. Additionally, it drains various waste products from ovarian tissue. This result of the present study agrees with that described by Vijaya, Middha, Usha et al., 2012.

\subsection{Architecture of ovaries}

A very careful examination of various types of serial sections of both small and large ovaries, including those given in the text (Figures 1-11), showed no internal cavities. Neither small nor large lumens were seen in any part of the ovaries. The lack of lumens or internal cavities in ovaries in the present study clearly and strongly indicates that the ovaries of this oligochaetous clitellates are, in fact, solid and not hollow or sac-like structures as had erroneously been described (ECKELBARGER, 2006). Vice versa, sac-like ovaries are characteristics of hirudinean clitellates (leeches), a closely related group to oligochaetous clitellates.

\subsection{Zonation of ovaries}

The small and the large ovaries both showed histological zonation (Figures 1-3) during the breeding seasons. The small ovaries (Figure 2) showed only two distinct histological zones, $\mathrm{Zl}$ and $\mathrm{Z} 2$. Z1 was comparatively larger than Z2 and contained only oogonia OG. Some terminal OG showed mitotic figures, underwent division and produced two different cell types, the oocytes OCs and the trophocytes TCs, simultaneously. These two cell types, which were produced by dividing oogonia DOG constituted Z2. Z2 appeared too small in comparison with $\mathrm{Zl}$ because it was confined only to the free terminal tip of these small ovaries, which contained only few cells (OCs and TCs) (Figure 2). The TCs were too small and undeveloped, whereas the OCs were comparatively larger and prominent.

The large ovaries (Figures 1 and 3 ) demonstrated three histologically distinguishable zones: Z1, Z2 and Z3. Z1, which constituted the anterior original germinal zone of the ovaries, was intermediate in size and contained only OG. Some terminal DOG of Zl also showed mitotic figures (Figure 3), underwent division and produced two different cell types, the TCs and OCs simultaneously. These newly produced cells constituted Z2. Z2 was the smallest zone in these large ovaries and appeared as a narrow band between $\mathrm{Zl}$ and Z3 (Figure 3). Based on size, two subtypes of OCs were distinguished in Z2, the small and the medium oocytes. Both subtypes were yolkless. Therefore, they were called small previtellogenic oocytes SPVOCs and medium previtellogenic oocytes MPVOCs (Figure 3), respectively. Z3 was the largest zone in these large fully formed ovaries. It comprised about two-thirds of the whole ovarian bulk (Figures 1 and 3) and contained the fully formed TCs (Figures 3, 9 and 11) and the extremely large OCs, which were filled with yolk granules (Figures 3, 5-7 and 10). Hence, these OCs were called large vitellogenic oocytes LVOCs.

Zonation phenomenon of ovaries in the present study was, in fact, primarily caused by oogonia division and vitellogenesis, which have produced the germ and germ-line cells. But, it was secondarily caused by arrangement and/or distribution of these cells in ovary in a way that each zone contained certain types of germ and/or germ-line cells.

The present results of the ovarian regionalization are similar to those reported by Siekierska (2003). But are slightly dissimilar to those reported in E. kinnaeri (LAKHANI and KHATRI, 2008). They described only two zones in ovaries of E. kinneari instead of three. They reported that the first zone contained only the basal undifferentiated germ cells or oogonia, whereas the second one contained various types of oocytes. Thus, $\mathrm{Zl}$ in the present study is, certainly, comparable to the first zone of ovary in E. kinneari since both zones contained only OG. The slight disagreement was found in description of the second zone of ovary in E. kinneari, which has not been divided (as it is usually done) into two zones, $\mathrm{Z} 2$ and $\mathrm{Z} 3$. Thus, it contained both subtypes of oocytes (SPVOCs and MPVOCs) of Z2, in addition to the LVOCs of Z3.

\subsection{Types of cells in ovaries}

A thorough examination of the histological preparations of various types of ovarian serial sections revealed the presence of six principal types of cells. They were peritoneal cell PC, follicular cell FC, stromal cell SC, oogonium OG, oocyte OC 

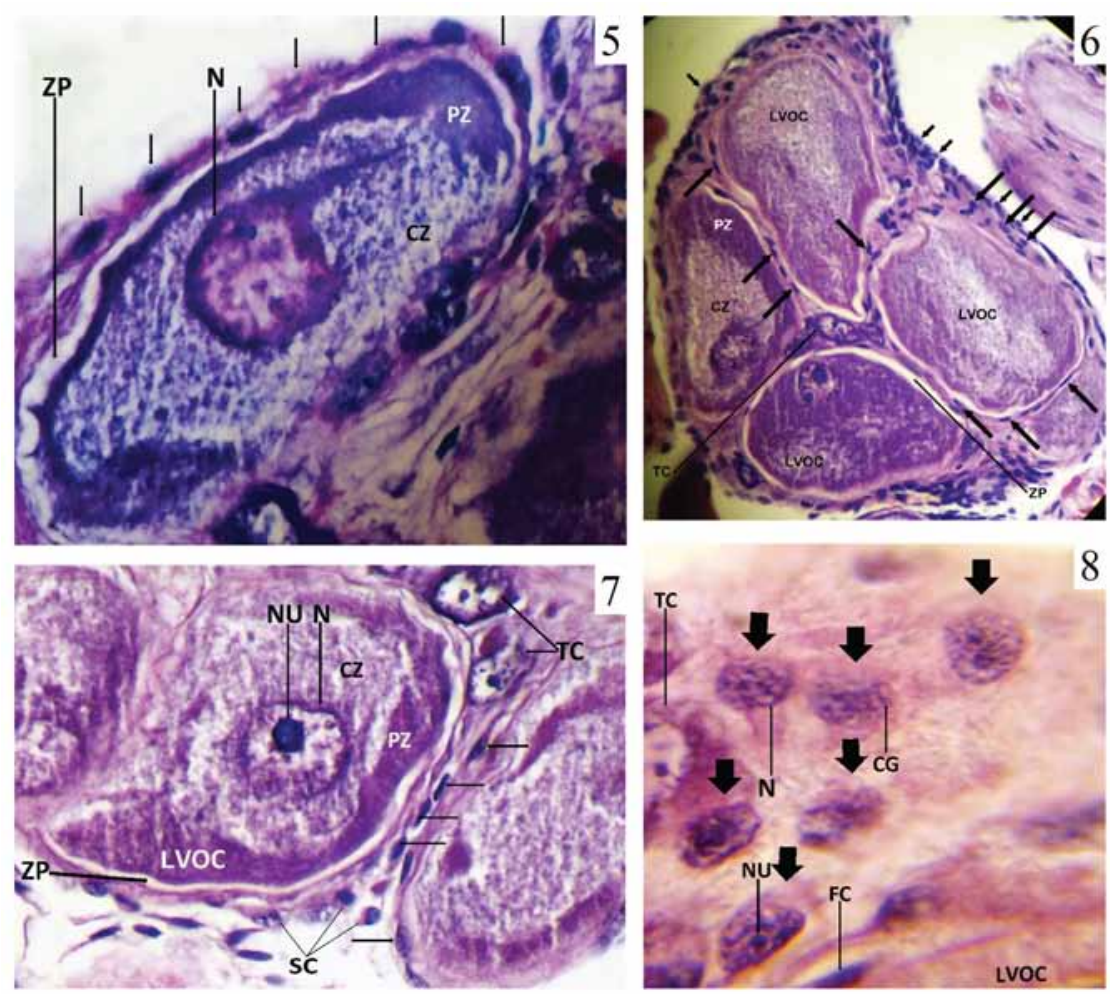

Figure 5-8. (5) A photomicrograph of a part of a longitudinal section of $\mathrm{Z} 3$ of ovary in $D$. atheca, during the breeding seasons showing a magnified large vitellogenic oocyte covered by a layer of follicular cells (short arrows). N- nucleus; ZP- zona pellucida; CZ- central yolky zone; PZ- peripheral yolky zone encroaching into ZP and dividing it into several small compartments (left lower corner of the figure); (6) A photomicrograph of a part of a cross section of the Z3 of ovary in $D$. atheca, during the breeding season showing four large vitellogenic oocytes LVOC. Thick arrows, peritoneal cells forming ovarian envelope, thin arrows, follicular cells forming ovarian cortex and enclosing the oocytes; TC- trophocyte; CZ-central yolky zone; PZ- peripheral yolky zone; ZP- zona pellucida; lower LVOC has two nucleoli; (7) A photomicrograph of a part of a cross section of zone Z3 of the ovary in D. atheca during the breeding seasons showing follicular cells (thin arrows) enveloping the large vitellogenic oocytes LVOCs; TC- trophocytes; SC- stromal cells forming the ovarian stroma; N.- nucleus; NU- nucleolus; ZP- zona pellucida; CZ- central yolky zone; PZ- peripheral yolky zone; (8) A photomicrograph of a part of a horizontal section of Z3 of the ovary in D. atheca, during the breeding seasons showing a group of highly magnified stromal cells (short thick arrows). CG- chromatin granule; N- nucleus and NU- nucleolus of the stromal cells; TC- a part of trophocyte; FC- a part of follicular cell nucleus; LVOC- a small part of a large vitellogenic oocyte.

and trophocyte TC (nurse cell). The first three types were somatic, whereas the other three were germ and germ-line. These cells were differentiated using several cell characteristics such as the shape, size and location of the cell, nucleus and nucleolus, in addition to the staining affinity of the cytoplasm, nucleus, nucleolus and chromatin threads and granules of the cell. The number of the main types of cells in ovaries in the present study differs from those reported in other oligochaetous clitellates. Siekierska $(2002,2003)$ described only four types (somatic cells, OG, OCs, TCs), whereas Urbisz, Krodkiewska and Swiątek (2010) reported five types (PCs, FCs, OG, OCs, TCs).

There is, in fact, a general agreement on the main types of the germ and germ-line cells (OG, OCs and TCs). But, somatic cells are, in fact, differently classified and termed by different authors. The results of the present study, concerning the types of germ and germ-line cells, are in line with those reported by Siekierska (2002, 2003), Lakhani and Khatri (2008) and Urbisz, Krodkiewska and Swiątek (2010). On the other hand, the present study demonstrated three distinct types of somatic cells (PCs, FCs, SCs). This result disagrees with that reported by Siekierska $(2002,2003)$, where all these cell types were collectively called somatic cells. They have not been divided into their own types. The present result also disagrees, but slightly, with that reported by Urbisz, Krodkiewska and Swiątek (2010), where only two types of somatic cells (PCs, FCs) were interchangeably described and used.

\subsubsection{Peritoneal cell}

PC (Figures 2 and 6) was a thin flattened elongated cell, which measured about $16 \mu \mathrm{m}$ in length and $6 \mu \mathrm{m}$ in width. The nucleus was spindle shaped and measured about $6 \mu \mathrm{m}$ in length and $2 \mu \mathrm{m}$ in width. The cytoplasm was poorly stained, whereas the nucleus was so intensely stained that it was impossible to see the nucleolus, if present. These cells were arranged in a single layer and formed a very thin peritoneal membrane, which enveloped both ovaries. When carefully examined and traced (Figure 2), these cells were, in fact, seen to be continuation of the peritoneal cell layer forming the innermost layer of the body wall (parietal peritoneum). They lined the longitudinal muscles of the body wall and the intersegmental septa ISS. It is well known that the innermost layer of body wall in 


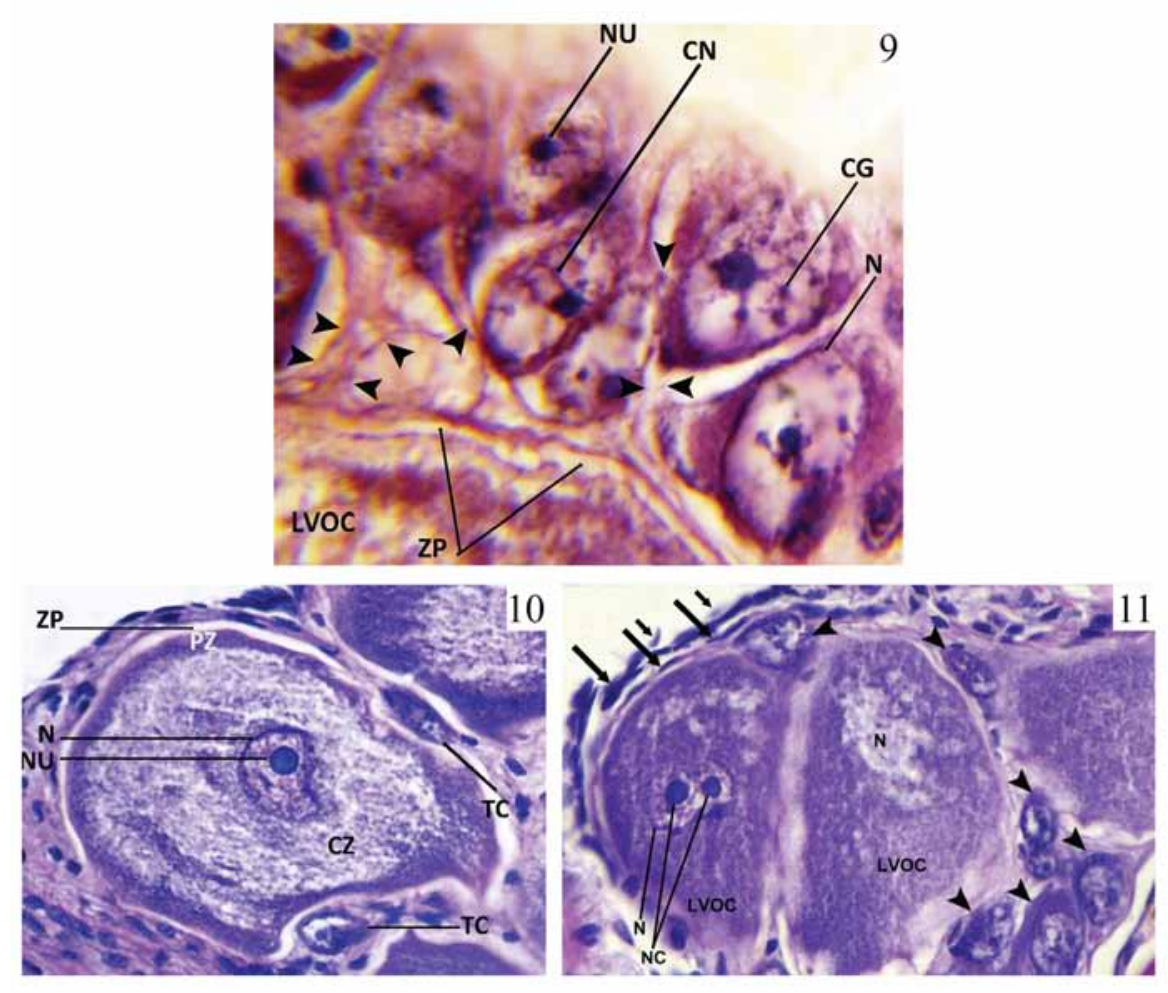

Figure 9-11. (9) A photomicrograph of a part of a horizontal section of Z3 of the ovary in D. atheca, during the breeding seasons showing a highly magnified chain of fully formed trophocytes, which accompanied a large vitellogenic oocyte LVOC (a part of which is seen just beneath these trophocytes). Intercellular cytoplasmic bridges between neighbouring trophocytes (single arrow heads) and between oocyte and the whole trophocytes chain (two pairs of opposite arrow heads, left middle part of the figure); ZP- zona pellucida; N, NU, CG and CN refer to nucleus, nucleolus, chromatin granule and chromatin network of trophocytes, respectively; (10) A photomicrograph of a part of longitudinal section of Z3 in ovary of D. atheca during the breeding seasons showing differential yolk deposition in a large vitellogenic oocyte. N- nucleus; NU- nucleolus; ZP- zona pellucida; CZ, PZ, central and peripheral zones of yolk granules, respectively; TC- trophocytes; (11) A photomicrograph of a part of longitudinal section of Z3 in the ovary of $D$. atheca during the breeding seasons showing two adjacent large vitellogenic oocytes LVOCs. Two nucleoli NU are seen in the left one; $\mathrm{N}$ - nucleus; arrow heads, trophocytes; short arrows, peritoneal cells; long arrows, follicular cells, forming ovarian cortex and oocyte envelope.

earthworms consists of a thin parietal peritoneal membrane, which usually lines the muscular layer of the body wall and the ISS. Since the ovaries in the present study were firmly tied to the muscles of the ISS12 (Figure 2), thus, they were also enveloped by PCs along with muscles of the ISS. This outer peritoneal membrane appears to act as an outer protective and/or supportive covering for the germ and germ-line cells of the ovaries. PCs have been reported to envelop the ovaries in other species of oligochaetous clitellates (ECKELBARGER, 2006). Additionally, PCs were differently named by different authors. In D. veneta (SIEKIERSKA, 2002), they have been called squamous epithelial cells. In T. tubifex, L. claparendeanus and P. bavaricus (URBISZ, KRODKIEWSKA and SWIĄTEK, 2010), they had been given two different names. They were called peritoneal cells and/or follicular cells at the same time. These different terms may cause confusion. It is, therefore, necessary to use uniform terms, as much as possible, to avoid confusion. Thereby, these cells, in the present study, were called peritoneal cells because they were, in fact, seen to be an extension or a continuation of the peritoneal membrane lining the body wall layers.

\subsubsection{Follicular cell}

FC (Figures 5 and 6) was a thin flattened elongated cell with a central swelling, where the nucleus was lodged. FC was larger than PC and measured about $25 \mu \mathrm{m}$ in length and $11 \mu \mathrm{m}$ in width. The nucleus was spindle-shaped and measured about $13 \mu \mathrm{m}$ in length and $6 \mu \mathrm{m}$ in width. It was so deeply stained that it was also impossible to detect the nucleolus. These cells were situated just inner to the peritoneal cells, which formed the outermost covering of the ovaries. They were usually arranged in two peripheral cell layers, which formed the ovarian cortex (Figure 6). Some FCs of the inner cortical layer deepened into the ovarian stroma (matrix), formed a thin single cell-layered envelope, which firmly enclosed the oocytes (Figure 6). FCs were seen in an immediate contact with zona pellucida ZP of the oocytes (Figures 5 and 6). Therefore, these cells were named as follicular cells. These results agree with those reported by (URBISZ, KRODKIEWSKA and SWIĄTEK, 2010). Location of these cells in the present study indicates that they are protective and/or supportive in nature. FCs were not seen scattered among the germ and germ-line cells. This means that they were not involved in the formation of ovarian stroma. 
FCs exhibited no signs of secretory activity. The non-glandular nature of the FCs clearly demonstrates that they play neither direct nor indirect nutritive role in nourishment of OCs, which they ensheathe. This result is similar to that reported by Siekierska (2003). These cells, which were called somatic cells in D. veneta, were reported to be non-glandular. The results of the present study concerning the role of FCs in formation of ovarian cortex and oocytes envelopes, agree with those reported by Siekierska (2003) and Urbisz, Krodkiewska and Swiątek, 2010. Contrariwise, the result of the present study regarding the role of FCs in the formation of ovarian stroma disagree with results of these authors. Functionally, FCs in the present study resembles the outer follicular cells OFCs, a subpopulation of FCs, described by Gouda (2012) and Ben Ahmed, Tekaya, Malota et al. (2013) in some hirudinean clitellates. The OFCs and not the inner follicular cells IFCs were reported by these authors to enclose the oocytes, whereas the IFCs were functionally similar to SCs in the present study.

\subsubsection{Stromal cell}

Stromal cell SC (Figure 8) was oval in shape and measured about $19 \mu \mathrm{m}$ in length and $12 \mu \mathrm{m}$ in width. These cells were somewhat similar to fibroblasts. They showed short, faintly stained cytoplasmic extensions. The nucleus was oval, comparatively large and measured about $13 \mu \mathrm{m}$ in length and $9 \mu \mathrm{m}$ in width. It contained many, but small scattered and moderately stained chromatin granules. Thus, the nucleolus, though small, was easily seen. It was slightly oval and measured about $2 \mu \mathrm{m}$ in length and $1.5 \mu \mathrm{m}$ in width. SCs and not FCs, in the present study, were seen scattered among the germ and germ-line cells, thus forming the ovarian stroma (Figures 7 and 8). Therefore, this cell type was called stromal cell. Position of the SCs strongly suggests that they were involved in the formation of the inner sustentacular and/or supportive ovarian stroma. This result is in line with those reported by Gouda (2012) and Ben Ahmed, Tekaya, Malota et al. (2013) in some leeches. They have reported the presence of two morphologically different subpopulations of follicular cells instead of one. These two distinct subtypes of FCs were called the outer follicular cells OFCs and the inner follicular cells IFCs. The OFCs were seen to surround the oocytes and trophocytes. Thus, they functionally resemble the FCs enclosing the oocytes in the present study. At the same time, the IFCs were seen scattered among the oocytes. Hence, they functionally resemble the newly described SCs in the present study. The results reported by Gouda (2012) and Ben Ahmed, Tekaya, Malota et al. (2013) strongly support the results of the present study concerning the functions of FCs and SC.

It is worth mentioning that from evolutionary point of view, oligochaetous clitellates and hirudinean clitellates are members of the same monophyletic taxon, Clitellata. Thus, it is possible that these closely related annelid clitellates may show several common characteristics. For example, all clitellates have clitellum, can form cocoon and are hermaphrodite. Thus, all members of clitellates are closely related to each other and they, in fact, do share many morphological, embryological, physiological characteristics and molecular data.

This somatic cell type in the present study was considered a new somatic cell type because it showed, in addition to their situation, several specific cell features, which were not seen in the other two somatic cell types (PCs and FCs). No such cell type has been previously reported in any other oligochaetous clitellate.

\subsubsection{Oogonium}

Oogonia OG were the basal undifferentiated female germ cells, which were restricted to $\mathrm{Zl}$ (Figures 2-4). They were overcrowded and the cell membranes and cytoplasm both were faintly stained. Thus, the cell boundaries, even when the cells were highly magnified (Figure 4), were not sharply demarcated. OGs were small oval cells, which measured about $15 \mu \mathrm{m}$ in length and $11 \mu \mathrm{m}$ in width. The cytoplasm formed a thin coat around a comparatively large distinct oval nucleus, which measured about $11 \mu \mathrm{m}$ in length and $8 \mu \mathrm{m}$ in width. The nuclear membrane was always ornamented with several large deeply stained chromatin granules. The nucleoplasm was faintly stained. No nucleolus could be seen in these cells. Some DOG in the posterior part of $\mathrm{Zl}$ (Figures 2 and 3 ) showed mitotic figures. They were able to produce two different cell types, the OCs and TCs simultaneously (Figure 2) and not only one type, the OCs, as had been previously considered. Presence of the TCs in ovaries in the present study means that the ovaries are, in fact, nutrimental (meroistic) and not panoistic at all.

Hence, the old view (DUMONT, 1969; CHAPRON and RELEXANS, 1971a, b; JAMIESON, 1981, 1992, 2006; ECKELBARGER, 2006), which had considered the ovaries of all oligochaetous clitellates panoistic (without trophocytes) is, in fact, incorrect and should no longer be accepted. Thus, the result of the present study clearly opposes this old view. Vice versa, the results of the present study are in line with and strongly support those reported by Paschma (1962), Siekierska (2002, 2003), Siekierska and UrbanskaJasik (2002), Lakhani and Khatri (2008), Urbisz, Krodkiewska and Swiątek, 2010, Urbisz and Swiatek (2013) and Faron, Bernas, Sas-Nowosielska et al. (2015). All these studies have shown that the ovaries of oligochaetous clitellates are, in fact, nutrimental. No recent study has supported the presence of panoistic ovaries in any oligochaetous clitellate. Thus, it can generally be concluded that all oligochaetous clitellates possess meroistic or nutrimental ovaries. Additionally, presence of trophocytes has well been documented (BEN AHMED, FUCHS, TEKAYA et al., 2010; GOUDA, 2012 and BEN AHMED, TEKAYA, MALOTA et al., 2013) in ovaries of hirudinean clitellates, which are closely related to oligochaetous clitellates. This clearly indicates that all clitrllate annelids have nutrimental ovaries.

\subsubsection{Trophocyte}

TCs (Figure 9) were oval in shape and measured about $30 \mu \mathrm{m}$ in length and $17 \mu \mathrm{m}$ in width. The cytoplasm exhibited strong staining affinity. The large oval nucleus occupied almost the whole perikaryon and measured about $21 \mu \mathrm{m}$ in length and $14 \mu \mathrm{m}$ in width. The nucleoplasm was faintly stained, whereas the nuclear membrane, chromatin granules and network and nucleolus showed moderate to strong staining affinity. The comparatively small spheroid eccentric nucleolus was intensely stained and measured about $3 \mu \mathrm{m}$ in diameter. TCs were produced by DOG. They appeared first in Z2 as small undeveloped cells (Figure 2) and were seen in immediate contact with OCs, which were slightly larger. Consequently, they increased in size and number and became fully formed and prominent in Z3 (Figure 9 and 11). They appeared in groups or chains adjacent to or in the vicinity of the LVOCs. 
Each chain accompanied an oocyte. The whole chain was connected to the accompanied oocyte via an intercellular cytoplasmic bridge ICCB of about $6 \mu \mathrm{m}$ in thickness (Figure 9). The closely fitted or adjacent TCs in the chain itself were also interconnected via ICCBs of about $4 \mu \mathrm{m}$ in thickness. This intimate structural connection between the OCs and the accompanied TCs or between the adjacent TCs in the same chain strongly suggests the occurrence of incomplete cell divisions. This intricate anatomical association between the OCs and TCs strongly supports that the latter play a direct nutritive role in the growth of the former and/or elaboration and deposition of yolk granules in the ooplasm. Additionally, presence of interconnected OCs and TCs, simultaneously in the present study strongly indicates that the ovaries of this oligochaetous clitellate are, in fact, nutrimental and not panoistic. The results of the present study are similar to those reported in D. veneta (SIEKIERSKA, 2002, 2003).

\subsubsection{Oocyte}

Oocyte OC was also produced by DOG along with TC and both were seen first in Z2. But unlike the small undeveloped TCs, the OCs were obvious (Figures 2 and 3). These small oocytes greatly increased in size and were fully formed in Z3 (Figures 3, 5-7, 10 and 11). Based on several cellular features such as the shape, size and location of cell, nucleus and nucleolus, in addition to the presence or absence of the yolk granules in the ooplasm, the OCs were subdivided into three subtypes the SPVOCs, MPVOCs and LVOCs.

The SPVOCs (Figures 2 and 3) were small oval OCs and measured about $30 \mu \mathrm{m}$ in length and $14 \mu \mathrm{m}$ in width. The oval nucleus measured about $15 \mu \mathrm{m}$ in length and $12 \mu \mathrm{m}$ in width, whereas the small oval nucleolus measured about $2 \mu \mathrm{m}$ in length and $1.5 \mu \mathrm{m}$ in width. SPVOCs underwent further growth and changed to MPVOCs (Figure 3), which measured about $50 \mu \mathrm{m}$ in length and $30 \mu \mathrm{m}$ in width. The oval nucleus was about $20 \mu \mathrm{m}$ in length and $15 \mu \mathrm{m}$ in width, whereas the oval nucleolus was about $5 \mu \mathrm{m}$ in length and $3 \mu \mathrm{m}$ in width. Both these subtypes were restricted to $\mathrm{Z} 2$ and were yolkless, therefore they were called previtellogenic oocytes PVOCs.

The LVOCs were restricted to Z3 (Figures 1, 3 and 6). They were formed from MPVOCs of Z2, which underwent further growth followed by vitellogenesis. They were oval in shape, extremely large and measured about (100-185) $\mu \mathrm{m}$ in length and (65-114) $\mu \mathrm{m}$ in width. Additionally, they have synthesized and/or acquired and deposited a huge amount of yolk granules in the ooplasm. Therefore, they were called large vitellogenic oocytes LVOCs. They showed two distinct yolky zones, a central and a peripheral (Figures 6 and 10). The central zone formed the inner core of the OCs, which surrounded the nucleus. It was comparatively wider and faintly stained. The peripheral zone formed the outer cortical coat of the OCs, which abutted zona pellucida ZP. It was comparatively narrower and deeply stained. The yolk granules of the central zone were scattered and evenly distributed, whereas those of the peripheral zone were, densely packed and overcrowded. The outer border of the peripheral zone was seen to encroach into the $\mathrm{ZP}$ of the LVOCs in several places and at different intervals (Figures 5 and 7 ) and divide it into several compartments. ZP formed the outermost unstained transparent non-cellular sheath or capsule of the LVOCs. The nucleus was large, oval, with an irregular nuclear membrane and measured about $34 \mu \mathrm{m}$ in length and $28 \mu \mathrm{m}$ in width. Usually, one distinct oval eccentric nucleolus measuring about $10 \mu \mathrm{m}$ in length and $8 \mu \mathrm{m}$ in width was seen. Presence of two nucleoli however was not uncommon (Figures 6 and 11). Appearance of two differently stained yolky zones in the LVOCs in the present study was, in fact, due to differential deposition and/or distribution of the yolk granules in the ooplasm. Since the granules of the central zone were somewhat scattered and evenly distributed in a comparatively large space, thus, they were faintly stained. Contrariwise, the granules of the peripheral zone were densely packed, overcrowded and confined to a comparatively small space, thus, they were deeply or intensely stained. The present results are similar to those reported by Siekierska $(2002,2003)$.

\section{Conclusions}

The principal conclusions, which were arrived at from the logical deductions of the results of the present comprehensive study, are: (1) ovaries of this oligochaetous clitellate are, in fact, nutrimental (meroistic) and not panoistic, because they have trophocytes (2) ovaries are undoubtedly solid and not sac-like structures, because they are completely devoid of any type of internal cavity (3) stromal cell the newly described somatic cell type, can be considered a new cell type, since it has its own distinct cellular features (4) ovarian stroma is formed by stromal cells and not follicular cells, as the former were seen scattered among the germ and germ-line cells (5) ovarian zonation is caused by production and/or arrangement of the germ and germ-line cells in various ovarian zones (5) somatic cells are sustentacular (supportive) and/or protective in nature; germ cells are proliferative (reproductive) and germ-line cells are nutritive (trophic) (6) yolk zonation of the ooplasm in LVOCs is due to differential deposition and/or distribution of the yolk granules in oocytes perikarya (7) presence of intercellular cytoplasmic bridges, which is of great nutritive value, is due to incomplete cell divisions in germ and germ-line cells.

Acknowledgements: Special thanks to Miss Vivian Najem Shlemoon (M.Sc. IT, University of Wollongong, Australia) and Meelad Najem Shlemoon (MBBS, University of Mosul) for their technical assistance. The authors also wish to acknowledge the support, help and encouragement of Dr. Wijdan M.S. Mero, Head of the Department of Biology, Dr. Fadhil H. Easif, Dean of faculty of Science and Dr. Lazgin A. Jamil, President of University of Zakho.

\section{References}

BEN AHMED, R., FUCHS, AZ., TEKAYA, S., HARRATH, AH. and ŚWIĄTEK, P. Ovary cords organization in Hirudo troctina Johnson, 1816 and Limnatis nilotica (Savigny, 1822) (Clitellata, Hirudinea). Zoologischer Anzeiger, 2010, vol. 249, n. 3-4, p. 201-207. http:// dx.doi.org/10.1016/j.jcz.2010.08.004.

BEN AHMED, R., TEKAYA, S., MALOTA, K. and SWIATEK, P. An ultrrastructural study of the ovary cord organization and oogenesis in Erpobdella johanssoni (Annelida, Clitellata: Hirudinida). Micron: the international research and review journal for microscopy, 2013, vol. 44, p. 275-286. PMid:22921789. http://dx.doi.org/10.1016/j. micron.2012.07.005.

CHAPRON C. and RELEXANS, JC. Connexion intercellularies et evolution nucleaire au cours de la premeiose ovocytarie: etude ultrastructuralechez le Lombricien Eisenia foetida. Comptes rendus de l'Academie des sciences Paris, 1971a, vol. 272, p. 3307-3310.

CHAPRON, C. and RELEXANS, JC. Ultrastructure des gonocytes primordiauxet des gonies chez l'hermaphrodite Eisenia foetida 
(Oligochete Lombricide). Comptes redus de l'Academie des sciences Paris, 1971b, vol. 272, p. 2916-2919.

CULLING, CFA., ALLISTON, RT. and BARR, WT. Cellular pathology technique. 4th ed. London: Butterworth and Co. Ltd., 1985.

DUMONT, JN. Oogenesis in the annelid Enchytraeus albidus with special reference to the origin and cytochemistry of yolk. Journal of Morphology, 1969, vol. 129, n. 3, p. 317-344. http://dx.doi. org/10.1002/jmor.1051290305.

ECKELBARGER, J. Ogenesis. In ROUSE, G. and PLEIJEL, F. (Eds.). Reproductive biology and phylogeny of Annelida. Enfield: Science Publishers, 2006, p. 23-43.

FARON, J., BERNAS, J., SAS-NOWOSIELSKA, H. and KLAG, $\mathrm{J}$. Analysis of the behaviour of mitochondria in the ovaries of the earthworm, Dendrobaena veneta (Rosa, 1986). PLoS One, 2015, vol. 10, n. 2, p. e0117187. PMid:25671521. http://dx.doi.org/10.1371/ journal.pone.0117187.

GOUDA, HA. Oogenesis, vitellogenesis and cocoon secretion in two freshwater leeches from Assiut. Research Zoology, 2012, vol. 2, p. 47-59.

HIRAO, Y-H. Reproductive system and oogenesis in the freshwater oligochaete, Tubifex hattai. Journal of Faculty of Science Hokaido University Ser VI Zoology, 1964, vol. 15, n. 5, p. 439-448.

JAMIESON, BGM. The ultrastructure of the Oligochaeta. New York: Academic Press, 1981.

JAMIESON, BGM. Oligochaeta. In HARRISON, FW., GARDINER, SL. (Eds). Microscopic anatomy of invertebrates. New York: Wiley-Liss, 1992. p. 217-322. Annelida, vol. 7.

JAMIESON, BGM. Non-leech Clitellata. In ROUSE, G., PLEIJEL, F. (Eds). Reproductive biology and phylogeny of Annelida. Enfield: Science Publishers, 2006. p. 235-392.

LAKHANI, L. and KHATRI, A. Effect of rogor on the ovary of earthworm, Eudichogaster kinneari (Stephenson): A histological and histochemical profile. Journal of Environmental Research and Development, 2008, vol. 2, p. 378-385.

LAKHANI, L. Effect of three commonly used insecticides on histomorphology and histochemistry of ovary of an earthworm Eudichogaster kinneari (Stephenson). International Research Journal Biological Sciences, 2014, vol. 3, n. 12, p. 29-36.

LUNA, L. Manual of histologic staining method of the armed forces institute of pathology. 3rd ed. New York: McGraw-Hill, 1968.
PARTHASARATHI, K. and RANGANATHAN, LS. Influence of pressmud on the development of the ovary, oogenesis and neurosecretory cells of the earthworm, Eudrilus engeniae (Kinberg). African Zoology, 2000, vol. 35, n. 2, p. 281-286. http://dx.doi.org/10.1080/156 27020.2000.11657100.

PASCHMA, M. The structure of the ovary and oogenesis in Enchytraeus albidus Henle. Zoologica Poloniae, 1962, vol. 12, p. 145-188.

SIEKIERSKA, E. and URBANSKA-JASIK, D. Cadmium effect on the ovarian structure in earthworm, Dendrobaena veneta (Rosa). Environmental Pollution, 2002, vol. 120, n. 2, p. 289-297. PMid:12395841. http:// dx.doi.org/10.1016/S0269-7491(02)00152-5.

SIEKIERSKA, E. The structure of the ovary and oogenesis in gonadotropin-deprived earthworm, Dendrobaena veneta (Rosa). Zoologica Poloniae, 2002, vol. 47, n. 3-4, p. 37-48.

SIEKIERSKA, E. The structure of the ovary and oogenesis in the earthworm, Dendrobaena veneta (Annelida, Clitellata). Tissue \& Cell, 2003, vol. 35, n. 4, p. 252-259. PMid:12921708. http://dx.doi. org/10.1016/S0040-8166(03)00038-7.

SIEKIERSKA, E. Changes in the ovary cells structure in the earthworm, Dendrobaena veneta (Rosa) in neurosecretion deficiency and after exposure to cadmium. European Journal of Soil Biology, 2007, vol. 43, p. 311-315. http://dx.doi.org/10.1016/j.ejsobi.2007.08.034.

URBISZ, AZ. and SWIATEK, P. Ovary organization and oogenesis in two species of Lumbriculida (Annelida, clitellata). Zoology, 2013, vol. 116, n. 2, p. 118-128. PMid:23375544. http://dx.doi.org/10.1016/j. zool.2012.10.003

URBISZ, AZ., KRODKIEWSKA, M. and SWIĄTEK, P. Ovaries of Tubificinae (Clitellata, Naididae) resemble ovary cords found in Hirudinea (Clitellata). Zoomorphology, 2010, vol. 129, n. 4, p. 235-247. PMid:21170399. http://dx.doi.org/10.1007/s00435-010-0116-6.

VIJAYA, TM., MIDDHA, SK., USHA, T., SAINI, D. and GOVINDARAJ, G. Histological studies of the ovary and the oviduct of the vermicomposing earthworm from Indian subcontinent. International Journal of Fundamental and Applied Sciences, 2012, vol. 1, n. 1, p. 3-6.
Received March 7, 2017

Accepted August 7, 2017 